\title{
Experiments on the Effects of Dissolved Oxygen on the Free and Immobilization Effective Microorganisms (EM) in Treating Polluted River Water
}

\author{
Min JI, Jianzhong ZHU*, Ruirui ZHU \\ Key Laboratory for Integrated Regulation and Resources \\ Exploitation on Shallow Lakes \\ Ministry of Education, Hohai University, \\ Nanjing Jiangsu, 210098 China; \\ College of Environment \\ Hohai University, Nanjing, 210098, China \\ E-mail: jiminloveallen@163.com \\ *zhuhhai2010@hhu.edu .cn
}

\begin{abstract}
The immobilization of effective microorganisms (EM) on matrix supports is of great importance for improving microbes' density and avoiding microbes flooding so as to enhance removal efficiency in polluted river water. What's more, DO is of great importance in the wastewater treatment. Based on the previous study, the effects of dissolved oxygen (DO) on the activities of EM and IAEM (minerals adsorbing EM embedded by sodium alginate) were also investigated in polluted river water. The results showed that with abundant DO, removal efficiency of $\mathrm{NH}_{3}-\mathrm{N}$, TP and COD for EM and IAEM were increased by $(34.34 \%, 18.18 \%, 4.59 \%)$ and $(5.71 \%, 5.06 \%, 2.79 \%)$, which demonstrated EM alone was more adaptive to survive and reproduce under aerobic conditions, while immobilized microbes could better overcome the limitation of DO.
\end{abstract}

Keywords-immobilization; compound mineral; sodium alginate; effective microorganisms; dissolved oxygen

\section{INTRODUCTION}

According to statistics, presently there is almost not one complete natural river in the world and the serious damage of urban rivers has been recognized as a global ecologically environmental problem [1]. In our country, economic development has undoubtedly led to the deterioration of aquatic environment: serious urban rivers pollution and widespread aquatic eutrophication, which have serious impact on the residents' health of body and mind [2-5]. Therefore, aquatic environment recovery has become the indispensible content of environmental protection in China. Urban polluted aquatic treatment is very difficult because of its large work quantities and broad involved aspects [6-9]. Thus, looking for a cheap, efficient and environmentally friendly processing technology has always been the main topic of the water environmental governance in China.

High efficient bacteria degrading aquatic pollutants as the key to the bioremediation technology has been researched for many years [10-13]. Immobilized technology, fixing complete microbial cells to a certain extent, can contribute to improving the microbial cell density, degradation and tolerance ability of free cell to toxic substances and avoiding the loss of the microorganisms.

\author{
Jianbiao CHEN \\ Nantong Hydrographic Office, Nantong, Jiangsu, China \\ Chunyan WANG \\ Yancheng Environmental Monitoring Center, Yancheng, \\ Jiangsu, China
}

Now, of all immobilization methods, usage of suited natural or synthetic supports has drawn increasing popularity and been researched widely, which is largely due to the mild conditions needed and the low cost of the process. However, the effects of DO, as the leading factor affecting the water quality, on free microbes and immobilization microbes haven't been widely and deeply studied.

This study was based on the previous study in which, EM (free microbes) and IAEM (immobilizations) was studied to determine which was more effective to the removal of $\mathrm{NH}_{3}-\mathrm{N}, \mathrm{TP}, \mathrm{COD}$ in polluted river water. In this study, the effects of DO on these two materials and the lifecycle of effective organisms were investigated in polluted river water.

\section{MATERIALS AND METHODS}

\section{A. Synthetic Polluted River Water}

In this study, synthetic polluted river water contained glucose $\left(\mathrm{C}_{6} \mathrm{H}_{12} \mathrm{O}_{6}: 200 \mathrm{mg}\right)$, urea $\left(\mathrm{CO}\left(\mathrm{NH}_{2}\right)_{2}\right.$ : $\left.32 \mathrm{mg}\right)$, ammonium chloride $\left(\mathrm{NH}_{4} \mathrm{Cl}: 100 \mathrm{mg}\right)$, potassium phosphate $\left(\mathrm{KH}_{2} \mathrm{PO}_{4}: 32 \mathrm{mg}\right)$, sodium bicarbonate $\left(\mathrm{NaHCO}_{3}: 120 \mathrm{mg}\right)$, magnesium sulfate $\left(\mathrm{MgSO}_{4} \cdot 7 \mathrm{H}_{2} \mathrm{O}: 80 \mathrm{mg}\right)$, anhydrous calcium chloride $\left(\mathrm{CaCl}_{2}: 40 \mathrm{mg}\right)$ and trace amounts of ferrous sulfate $\left(\mathrm{FeSO}_{4} \cdot 7 \mathrm{H}_{2} \mathrm{O}\right)$ dissolved in distilled water $(1000 \mathrm{~mL})\left(\mathrm{NH}_{3}-\mathrm{N}=55 \mathrm{mg} / \mathrm{L}, \mathrm{TP}=7.8 \mathrm{mg} / \mathrm{L}, \mathrm{COD}=290 \mathrm{mg} / \mathrm{L}\right.$, $\mathrm{pH}=7.4)$. All reagents were of analytical reagent grade unless otherwise specified.

\section{B. Compound Mineral (A)}

Compound mineral was obtained from WACUMA TECHNOLOGY CORPORATION LTD, Shenzhen City. It was made by the weight copy of the components as following: hydroxyapatite (0.1-5), natural zeolite (40-65), quartz (1-10), albite (1-10), illite (1-10), attapulgite (10-40) and sepiolite $(0.1-5)$.

\section{Effective Microorganisms (EM)}

EM is a kind of complex and concentrated bacteria and also can be described as a multi-culture of coexisting anaerobic and aerobic beneficial microorganisms. The main species involved in EM include: Lactic acid bacteria: 
Lactobacillus plantarum, Lactobacillus casei, Streptoccus lactis; Photosynthetic bacteria: Rhodopseudomonas palustrus, Rhodobacter spaeroides; Yeasts: Saccharomyces cerevisiae, Candida utilis; Actinomycetes: Streptomyces albus, Streptomyces griseus. EM in this study was obtained from laboratory, with 20 billion viable organisms per gram strains.

\section{The Immobilization Material}

AEM: Take one copy of A dissolved in one copy of microbial supernatant for at least 2days; IAEM: Mix the AEM completely to be encapsulated with $4 \%$ alginate solution with the proportion of $1: 1$, then drip the mixture into the $5 \%$ calcium chloride solution, resulting in the

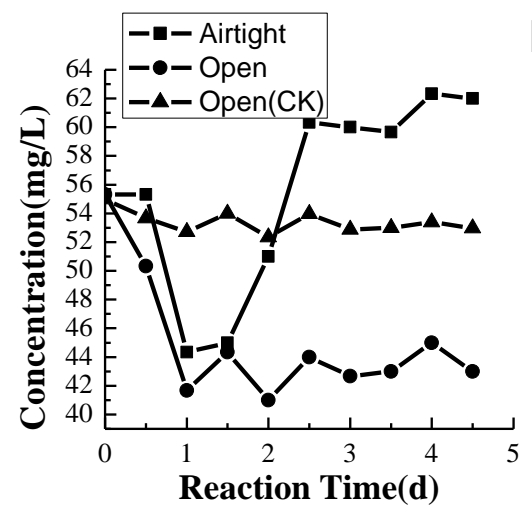

Fig. $1 \mathrm{NH}_{3}-\mathrm{N}$ values at airtight and open conditions

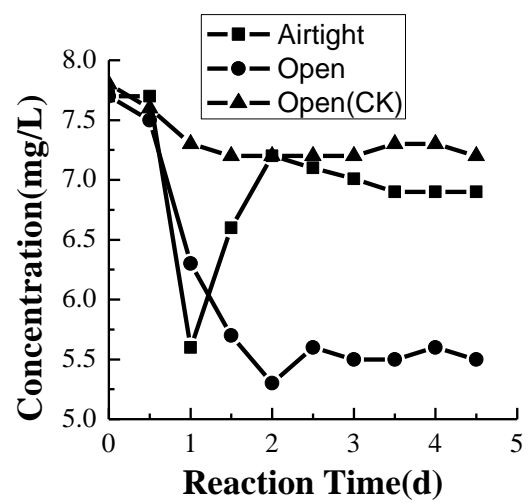

Fig. 3 TP values at airtight and open conditions

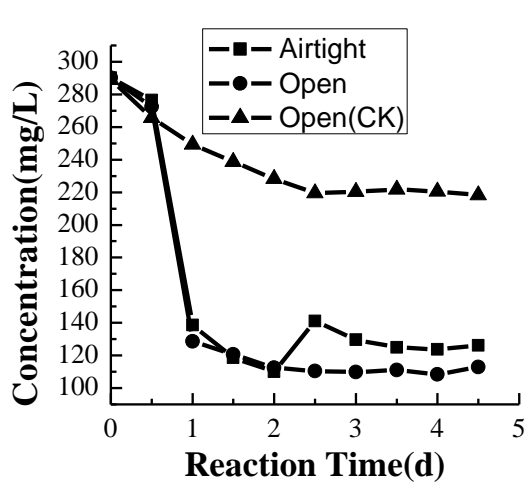

Fig. 5 COD values at airtight and open conditions

\section{EM}

EM

EM instantaneous formation of micro-particles.

\section{E. Experimental Methods}

1) Effect of DO on the removal efficiency of NH3-N, TP, $C O D$ for EM and IAEM: DO plays a significant role on the microorganisms' activity. Low DO will restrict the purifying process of wastewater. The airtight conical flask in the experiment can lead to low and even none DO after several days, which cause the worse water quality, while in open air, wastewater can touch enough DO.

At the two different conditions, airtight and open, processing effects of free and immobilized microorganisms were investigated respectively.

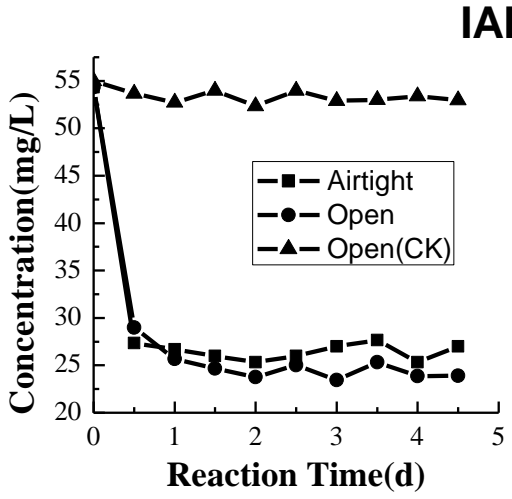

Fig. $2 \mathrm{NH}_{3}-\mathrm{N}$ values at airtight and open conditions

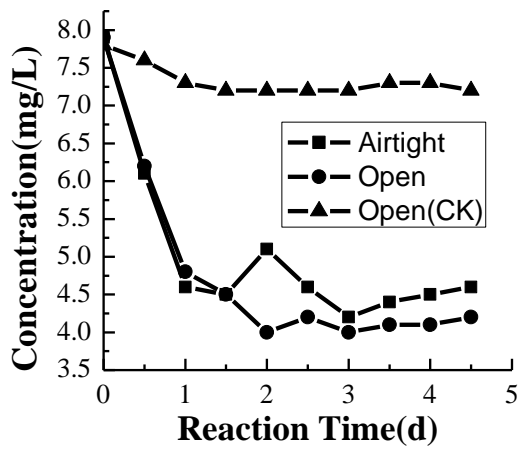

Fig. 4 TP values at airtight and open conditions

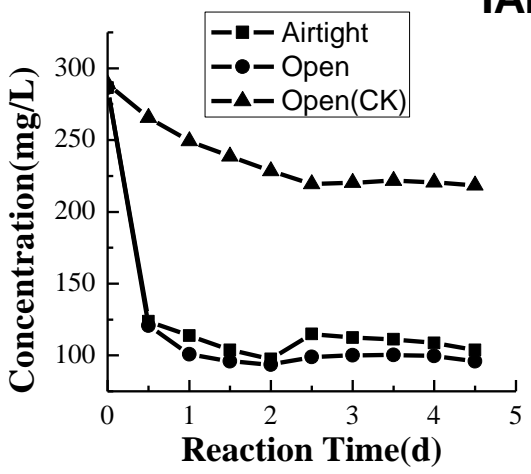

Fig. 6 COD values at airtight and open conditions 


\section{RESULTS AND DISCUSSION}

When DO was on the high side, all indicators of the control group appeared no more than the initial values during the reaction time (Fig.1, Fig.2, Fig.3, Fig.4, Fig.5, Fig.6). It was because in open state, under the condition of enough dissolved oxygen and organic matter, microorganisms in the air used the pollutants in the wastewater to purify the polluted water. In addition, the results of the effect analysis of DO for EM and IAEM were compared: DO did have effects on EM and IAEM, especially on free microorganisms (EM); High level DO helped to extend microbes' action duration, at the same time, helped to increase the removal efficiency of $\mathrm{NH}_{3}-\mathrm{N}$, TP and COD, especially in $\mathrm{NH} 3-\mathrm{N}$ and $\mathrm{TP}$, which respectively increased by $34.34 \%$ and $18.18 \%$ (table 1); For IAEM, though the removal efficiency of $\mathrm{NH}_{3}-\mathrm{N}$, TP and COD were not improved obviously, it appeared obviously stable in the process of water purification (table 1). $24 \mathrm{~h}$ after directly investing free microbes, wastewater became to gradually go into the level of low DO, thus, it was easily restricted by DO and free microbes action time became short. For immobilizations, because of embedded microbes' not one-time release into the water, microbial activity could last longer and microbes could play a better performance of water purification. Two typical strains degrading $\mathrm{NH}_{3}-\mathrm{N}$ and TP were mainly nitrifying bacteria and phosphorus accumulating bacteria, by which, $\mathrm{NH}_{3}-\mathrm{N}$ could be converted to other forms of inorganic nitrogen and $\mathrm{PO}_{4}{ }^{3-}$ could be absorbed, while the COD degradation could be achieved by various types of aerobic and anaerobic organisms, which of less effect than nitrifying bacteria and phosphorus accumulating bacteria by DO. That's also why the COD process showed more stable. In summary, such effective microbes were more adaptive to survive and reproduce under aerobic conditions, while immobilized microbes could better overcome the limitation of DO.

TABLE 1 Removal EFFICIENCY INCREASING VALUES OF $\mathrm{NH}_{3}-\mathrm{N}$, TP AND COD FOR EM AND IAEM

\begin{tabular}{|c|c|c|c|}
\hline \hline Type Indicator & $\mathbf{N H}_{\mathbf{3}}-\mathbf{N}(\boldsymbol{\%})$ & $\mathbf{T P}(\boldsymbol{\%})$ & $\mathbf{C O D}(\boldsymbol{\%})$ \\
\hline EM & 34.34 & 18.18 & 4.59 \\
\hline IAEM & 5.71 & 5.06 & 2.79 \\
\hline
\end{tabular}

\section{CONCLUSIONS}

Free effective microbes are more adaptive to the aerobic environment, while after immobilization, microbes can better adapt to environmental changes. Although sodium alginate embedding microbes shows evident advantages in the wastewater treatment, considering the size of $3 \mathrm{~mm}$, it is not suitable for this kind of large particles to degrade rivers and lakes. Maybe it will be a good choice to minimize the volume of the immobilization and increase the surface area as much as possible, without damaging their effects.

\section{ACKNOWLEDGEMENTS}

Financial support for this research was provided by the Scientific Research Starting Foundation for Returned Overseas Chinese Scholars, Ministry of Education, China (Grant No. 1061-51200312), the National Science Fund for Distinguished Young Scholars (Grant No. 50925932) and the Fundamental Research Funds for the Central Universities, China (Grant No. B09020222). Water Conservancy Research Funds, JiangSu (1061-51146012). Water Conservancy Research Funds, JiangSu (1061-5126312).

\section{REFERENCES}

[1] Chmiel S, Głowacki S, Michalczyk Z, et al. Some issues in the assessment of eutrophication of river waters as a consequence of the construction of a storage reservoir (on the example of the Bystrzyca River)[J]. Ecohydrology \& Hydrobiology. 2009, 9(2): 175-179.

[2] Zhang E, Liu E, Jones R, et al. A 150-year record of recent changes in human activity and eutrophication of Lake Wushan from the middle reach of the Yangze River, China[J]. Journal of Limnology. 2010, 69(2): 235-241.

[3] O Hare M T, Clarke R T, Bowes M J, et al. Eutrophication impacts on a river macrophyte[J]. Aquatic Botany. 2010, 92(3): 173-178.

[4] Le C, Zha Y, Li Y, et al. Eutrophication of lake waters in China: cost, causes, and control[J]. Environmental Management. 2010, 45(4): 662-668.

[5] Li Y, Cao W, Su C, et al. Nutrient sources and composition of recent algal blooms and eutrophication in the northern Jiulong River, Southeast China[J]. Marine pollution bulletin. 2011, 63(5): 249-254.

[6] Mayer J, Scheid S, Widmer F, et al. How effective are 'Effective microorganisms (EM)'? Results from a field study in temperate climate [J]. Applied Soil Ecology. 2010, 46(2): 230-239.

[7] Shalaby E A. Prospects of effective microorganisms technology in wastes treatment in Egypt[J]. Asian Pacific journal of tropical biomedicine. 2011, 1(3): 243-248.

[8] Xu X, Chen X, Fan Y. Screening and Domestication of High Effective Microorganism Used in Oil Containing Wastewater Remediation[J]. Journal of Water Resource and Protection. 2009, 1(2): 145-151.

[9] Guizhong Z, Jing S. Study on Effective Microorganisms Bacteria for Acrylonitrile Wastewater Treatment[C]. IEEE, 2010.

[10] Cho E, Kim E, Pan J. Adsorption immobilization of Escherichia coli phytase on probiotic Bacillus polyfermenticus spores[J]. Enzyme and microbial technology. 2011, 49(1): 66-71.

[11] Soldatkin O O, Kucherenko I S, Shelyakina M K, et al. Application of Different Zeolites for Improvement of the Characteristics of a $\mathrm{pH}-\mathrm{FET}$ Biosensor Based on Immobilized Urease[J]. Electroanalysis. 2013, 25(2): 468-474.

[12] Wang J J, Swaisgood H E, Shih J C. Bioimmobilization of keratinase using Bacillus subtilis and Escherichia coli systems[J]. Biotechnology and bioengineering. 2003, 81(4): 421-429.

[13] Könst P M, Turras P, Franssen M C, et al. Stabilized and Immobilized Bacillus subtilis Arginase for the Biobased Production of NitrogenContaining Chemicals[J]. Advanced Synthesis \& Catalysis. 2010, 352(9): 1493-1502.

[14] Wang Q, Yang Y, Li D, et al. Treatment of ammonium-rich swine waste in modified porphyritic andesite fixed-bed anaerobic bioreactor[J]. Bioresource Technology. 2012, 111: 70-75. 